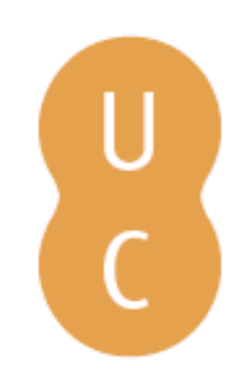

\title{
nommalina
}

\section{Hand Gestures and speech production in the booth: do simultaneous interpreters imitate the speaker?}

\author{
Autor(es): $\quad$ Galvão, Elena Zagar \\ Publicado por: Imprensa da Universidade de Coimbra \\ URL \\ persistente: URI:http://hdl.handle.net/10316.2/32258 \\ DOI: $\quad$ DOI:http://dx.doi.org/10.14195/978-989-26-0714-6_7 \\ Accessed : $\quad$ 26-Apr-2023 16:10:23
}

A navegação consulta e descarregamento dos títulos inseridos nas Bibliotecas Digitais UC Digitalis, UC Pombalina e UC Impactum, pressupõem a aceitação plena e sem reservas dos Termos e Condições de Uso destas Bibliotecas Digitais, disponíveis em https://digitalis.uc.pt/pt-pt/termos.

Conforme exposto nos referidos Termos e Condições de Uso, o descarregamento de títulos de acesso restrito requer uma licença válida de autorização devendo o utilizador aceder ao(s) documento(s) a partir de um endereço de IP da instituição detentora da supramencionada licença.

Ao utilizador é apenas permitido o descarregamento para uso pessoal, pelo que o emprego do(s) título(s) descarregado(s) para outro fim, designadamente comercial, carece de autorização do respetivo autor ou editor da obra.

Na medida em que todas as obras da UC Digitalis se encontram protegidas pelo Código do Direito de Autor e Direitos Conexos e demais legislação aplicável, toda a cópia, parcial ou total, deste documento, nos casos em que é legalmente admitida, deverá conter ou fazer-se acompanhar por este aviso.

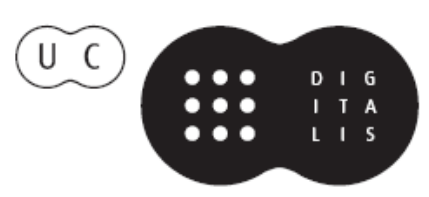




\section{ESTUDOS DE \\ LINGUÍSTICA}

VOLUME II

CONCEIÇÃO CARAPINHA

ISABEL A. SANTOS

COORD.

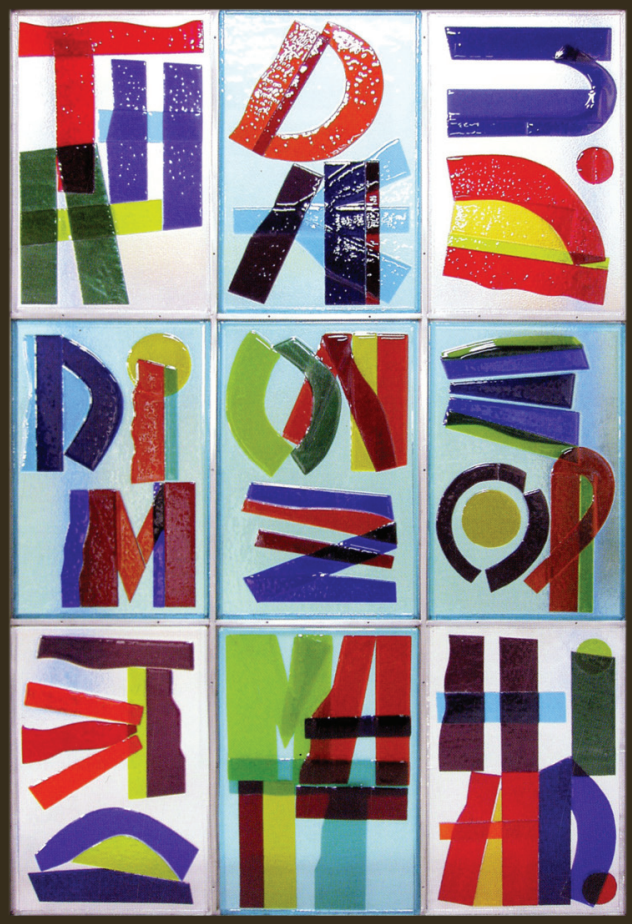




\section{HAND GESTURES AND SPEECH PRODUCTION IN THE BOOTH: DO SIMULTANEOUS INTERPRETERS IMITATE THE SPEAKER? 75}

Elena Zagar Galvão Centro de Linguística da Universidade do Porto (CLUP) Faculdade de Letras da Universidade do Porto (FLUP) elenazagar@gmail.com

\section{Introduction}

In the past two decades several studies conducted within various fields of knowledge (sociolinguistics, psychology, psycholinguistics, ethnography, anthropology, gesture studies, second language acquisition, etc.) have focused on the function of gestures and their relation to speech in face-to-face interaction in multiple contexts and situations. However, little research has been done on this relation in simultaneous interpreting (SI). In simultaneous interpreting, the interpreter's discourse is an online rendition, in another language, of somebody else's speech production. The concepts expressed in the original speech have to be comprehended and 'repackaged' to fit the constraints of the target language, all of this while the interpreter is monitoring his/her own speech production and performance. A legitimate question, therefore, is whether the interpreter's speech and accompanying gestures imitate the speaker's speech and accompanying gestures.

75 The author wishes to thank Isabel Galhano, Adam Kendon, and Paulo Galante for their invaluable help. 
This paper presents possible preliminary answers to this question and is part of an ongoing doctoral research project. The paper is divided into six sections. After this brief introduction, section two defines simultaneous interpreting, stresses its complexity both as a cognitive process and as a specific communicative situation, and sets forth the objectives of the study. Section three outlines the theoretical framework used and clarifies major concepts such as spontaneous co-speech gesture, gesture phrase, and descriptive gesture. Section four briefly describes the experiment and methods. Section five presents some examples of spontaneous co-speech gestures drawn from the experiment. Finally, section six outlines some preliminary conclusions and briefly discusses their theoretical implications.

\section{Simultaneous Interpreting: a complex communicative situation}

According to Pöchhacker's reworking of a 1960 definition by Otto Kade, "Interpreting is a form of Translation in which a first and final rendition in another language is produced on the basis of a one-time presentation of an utterance in a source language.” (Pöchhacker, 2004:11). Unlike most general definitions of interpreting, which stress the 'oral' medium of Interpreting as opposed to the 'written' medium of Translation, this definition subsumes Interpreting in the heading of Translation but highlights the 'transitoriness' of both the 'source text' and the 'target text' (or product) of Interpreting. Simultaneous Interpreting (SI), on the other hand, is a specific mode of interpreting which can be described as "spoken-language interpreting with the use of simultaneous interpreting equipment in a sound-proof booth" (Pöchhacker 2004: 19). Whenever we characterize SI, it is important to bear in mind the following: simultaneous interpreters may belong to the speakers' or to the audiences' language / cultural communities (or to neither). They constitute a third, mediating element between two interlocutors, one of whom, the speaker, plays an active role, while the other, the audience, generally plays a more passive role. The degree of 'activity' or 'passivity' of one and the other largely depends on the overall degree of formality socially stipulated and accep- 
ted for a specific situation (a conference, a meeting, a General Assembly, etc.), but simultaneous interpreters will always be, as it were, 'stuck' in the middle. As officially designated social 'mediators' between two parties who could not otherwise communicate efficiently, they must recreate the speaker's speech in a different language, making sense of the incoming speech as well as the speaker's accompanying gestures and other body movements while monitoring their own production and performance online. Thus, interpreters are in a doubly subordinate position, as they are forced to rely on the speaker's speech (and, quite often, also power point presentations, images, etc.) to produce meaning for the audience and, at the same time, they are at the speaker's and audience's service. In addition, while speakers can use speech and body to convey their message to the audience, but have to rely on the interpreter's speech to communicate with the people in the audience who do not understand their language, interpreters use speech and body, but they are confined to the booths where they work. It is rather surprising, in fact, that the audience is able to construct meaning from looking at a speaker while listening to a disembodied voice entering their ears through headphones, a voice which, they are told, is actually saying what the speaker is saying, but in a different language. However, this voice belongs to someone, and if most hand gestures occur during speech (McNeill, 1992: 4), then it is legitimate to ask what the body to which that voice belongs is doing while producing the interpreted speech. Does that body engage in gesturing??6 If so, are the speech and gestures produced by the interpreter formally, semantically or functionally similar to the speech and gestures produced by the speaker? The following sections will give a tentative answer to these questions by focussing on instances of descriptive co-speech gestures produced by four professional simultaneous interpreters in an experimental setting.

\footnotetext{
76 Spontaneous gestures are usually associated with face-to-face interaction and dialogic situations. Although SI is normally (and in our opinion, erroneously) defined as monologic, it presupposes the existence of an audience and, therefore, of an interlocutor.
} 


\section{Spontaneous Gestures: basic concepts}

A number of experimental and observational studies conducted in the past four decades in various fields of knowledge suggest that speech and gesture constitute one system. In other words, language is verbal as well as gestural (McNeill, 1992, 2000; de Ruiter, 2000). Besides having an important communicative function, spontaneous gesturing also seems to play a fundamental role for the communicators themselves by helping them in various ways such as, for instance, by relieving their cognitive effort (Goldin-Meadow, 2003), aiding in the organization of spatial information (de Ruiter, 2000) or in the retrieval of lexical items (Krauss et al., 2000). According to Adam Kendon (2004), co-speech gestures are forelimb actions (often involving also head and trunk) accompanying utterance production. These movements belong to the left-hand side of Kendon's continuum (Figure 1), they are closely related to speech semantically and are quasi-synchronous with it.

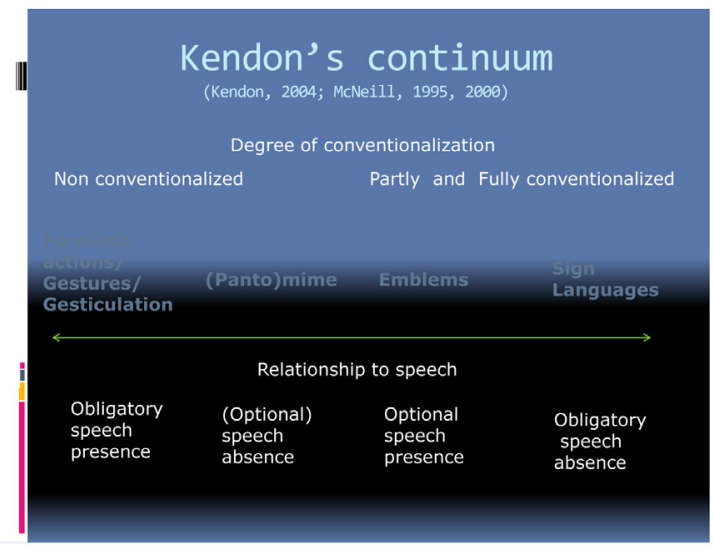

Figure 1 - Kendon's continuum

Simply put, a gesture phrase (Kendon, 2004: 108-112) is an excursionary movement of the hands and arms (most of the times also accompanied by movements of the trunk and head as well as facial expressions) organized into 3 main phases: preparation, stroke and retraction. The stroke is the peak in the movement and the most meaningful part of a gesture 
phrase. In gesture phrases, the mode of expression is global and holistic, the form is idiosyncratic, and speakers are not completely aware of their forelimb movements. It is important to note that the participants in an interaction usually perceive gestures as an integral part of utterance production and are only subliminally aware of their presence.

Instead of using one of the various typologies of gestures available in the literature (Ekman / Friesen, 1969; McNeill, 1992; Krauss et al., 2000; Kendon, 2004; Bavelas et al, 1995), this paper adopts Kendon's classification of gesture functions but concentrates on examples of co-speech gestures with a descriptive function. According to Kendon (2004), who claims that his classification is not a typology, gestures are "utterances as visible action" in the etymological sense of the word utterance, meaning 'putting out into the world' (Kendon, personal communication) . They can point to objects in the real or imaginary world (gestures used for 'pointing'); they can describe, model or enact real or abstract objects, actions, ideas, and situations (gestures used for 'description'); they can regulate interaction among participants (gestures used for 'interaction regulation'); and they can highlight aspects of discourse structure, mark the type of speech act a speaker is engaged in or show the speaker's attitude to what is being said (gestures used for 'pragmatic' purposes). Thus, spontaneous gestures only acquire meaning when observed and analysed within the communicative situation in which they occur and in strict conjunction with the speech they are part of. Furthermore, they can reinforce the verbal meaning of an utterance (or add other layers of meaning. Gestures, like words, are polysemous and polyfunctional.

\section{The experiment: materials, subjects and methods}

After this necessarily brief explanation of the general theoretical underpinnings of the present study ${ }^{77}$, it is time to describe the approach

77 This is part of an ongoing doctoral research project under the supervision of Isabel Galhano Rodrigues (FLUP) and Luis Alonso Bacigalupe (Universidade de Vigo). 
used to answer the questions set forth in the introductory section. The purpose of this section, therefore, is to provide a concise report on the methods used to collect and process the data for this research project. It is important to note that there are very few studies to date which have examined and described co-speech gestures in simultaneous interpreting (Galhano-Rodrigues, 2007; Galhano-Rodrigues / Zagar Galvão, 2010; Zagar Galvão, 2009). This means that, in the absence of a clearly established methodological framework specifically devised for the phenomenon under study, researchers have to draw and adapt from models and practices which have proved useful in the study of other communicative situations, thereby adjusting existing models to suit their own particular object of study and research questions.

Given the difficulty in obtaining complete simultaneous interpreting data (video+audio) from observational settings (Pöchhacker, 2004: 199), the approach adopted was experimental. Four professional conference interpreters, two men and two women ${ }^{78}$, were filmed separately while interpreting the same speech in the simultaneous mode. The experiment simulated a remote simultaneous interpreting assignment which the subjects of the experiment may be asked to perform in their professional life. The three main reasons for this choice were: (1) remote interpreting is a fairly frequent situation nowadays in both the private and the institutional sectors, where conference interpreters are often required to work in a booth which is not in the same physical space as the speakers and/or audience and they follow the speaker on a computer screen; (2) the simulation of a remote interpreting situation seems ideal in an experimental setting as the speech being interpreted is always exactly the same; (3) in a remote interpreting setting, the interpreters see the speaker on screen but they

\footnotetext{
78 The two women and one of the men are in their late forties and early fifties; they all have a five-year degree in Modern Languages and Literature as well as post-graduate education (a specialization course in Translation, an MA in Planning and a PhD in Literature); three have been working as free-lance conference interpreters for approximately 20 years, while the youngest in the group has been a free-lancer for about 5 years; three are fulltime free-lancers, while one is a full-time teacher and part-time free-lancer. The youngest in the group is the only one who received formal interpreter education, having completed a European Master's in Conference Interpreting (EMCI). Two are members of the Portuguese interpreters association APIC (Associação Portuguesa de Intérpretes de Conferência)
} 
cannot usually see the audience listening to them. The way the filming was done, with a camera inside the booth and without a visible audience outside the booth, was considered to be a close approximation to this situation of simultaneous presence and absence of a 'tangible' audience.

The approximately 20-minutes speech to be interpreted was a 2007 TED Talk (http://www.ted.com/talks) by the renowned neuroscientist Vilayanur Ramachandra, focusing on complex brain processes such as the Capgras syndrome, ghost limbs and synaesthesia. The digital video recordings of the four interpreters and the speaker were transferred onto a PC and fed into a specific software programme for annotation of speech and gesture, ELAN. This application ${ }^{79}$ was especially designed to create multiple 'layers' of information, which correspond to different tiers where transcription of speech and annotation of different gesture phrases can be viewed simultaneously. The first 9 minutes of the original speech and the four interpretations were transcribed following the conventions of GAT (Gesprächsanalytisches Transkriptionssystem) (Selting et al., 1998) and formal and functional annotations of all the gesture phrases observable in this part of the data were introduced into ELAN. Speech was analyzed into tone units, i.e., chunks of speech production identified by prosodic features which correspond to units of discourse meaning (Kendon, 2004: 108)

Although the microanalysis took into account the four broad dimensions of gesture functions set forth by Kendon and mentioned above (Section 3), this paper will focus on examples of the speaker's and the four interpreters' descriptive co-speech gestures.

\section{Microanalysis of descriptive co-speech gestures}

This section presents four examples of descriptive gestures by the speaker and the four interpreters and analyzes the accompanying verbal

${ }^{79}$ ELAN can be downloaded free of cost from http://www.lat-mpi.eu/tools/elan/, where it is described as "a professional tool for the creation of complex annotations on video and audio resources." 
utterances. The first two examples (Tables 1 and 2) are taken from the opening sentences of the speech. In this part, the speaker presents the subject of the talk (the human brain), invites the audience to think about the larger implications of the subject, describes the subject (the human brain is a three-pound mass of jelly) and its potential, describes the main quality of the subject (recursive quality), names this quality (self-awareness), expresses his opinion as to what this quality represents in his field of study, and finally expresses his hopes for the future of his field of study.

Examples two and three (Tables 3 and 4) are taken from another part of the speech, in which the speaker gives a neurological explanation of the Capgras syndrome. In example three, the speaker explains this pathology by verbalizing and enacting the concept of cutting (the wire has been cut by the accident). In example four, the speaker enacts an imaginary telephone conversation between a patient suffering from Capgras syndrome and the patient's mother. Due to space limitations, example four is only shown in the form of a table (Table 4).

\subsection{Example 1: The Human Brain}

The pictures in Table 1 show the speaker and the interpreters presenting the subject of the talk. This table, along with the other three, allows for a comparison of the following elements: the form of the speaker's and interpreters' gesture strokes (i.e. the most meaningful part of the excursion movement, shown in each image), the accompanying speech (underneath each image) as well as the function of the stroke established in relation to speech (underneath the lines of speech). In this example, all the interpreters use descriptive gestures with one or both hands to illustrate and thus reinforce but also add to the meaning they are expressing in speech, i.e., holding an object in one's hands. The configurations of the strokes share similar formal traits, which is perhaps not surprising in this particular instance, given the limited range of body resources to refer to holding something in one's hands. However, each interpreter produces 
formally different strokes (using one or both hands, with hands more or less cupped, some adding the meanings of 'size', 'weight' and 'round shape' of the object being held, etc.). The language used is also different and, even when the main lexical items are the same, they are arranged in slightly different ways (e.g., Temos; Aqui temos; que pode ser segurada; que nós seguramos; que se pode agarrar, que conseguem agarrar; uma massa de geleia; essa massa gelatinosa, esta massa de geleia; pedaço de $\mathrm{gel}$ ). The units of meaning expressed also show some variation, with two interpreters verbalizing the weight of the 'mass of jelly' (três quilos; cinco quilos) and the other two omitting it from the verbal modality. It is also interesting to note that for the Speaker as well as for interpreters $M$ and $A$, the gestures in this sequence also have a pragmatic function in that they seem to serve as cohesive devices ${ }^{80}$ in their discourse. The third row of pictures shows that the main function of the five different gestures strokes is the same, i.e., to describe the semantic content by showing the action ('holding') and the location ('palm') of the topic/object ('brain'). Also to be noted is interpreter M's facial expression in image M2, which adds one more layer of meaning to the communicative situation by revealing the interpreter's attitude towards the object (a mass of jelly in her hands) and thus functioning as personal comment.

\subsection{Example 2: Recursive Quality}

The pictures in Table 2 show the speaker and two of the interpreters $^{81}$ ( $\mathrm{M}$ and $\mathrm{I}$ ) producing gestures which enact the abstract concept of 'recursiveness'. Formally, the gestures are not exactly the same: the speaker, with both hands in a bunch and both index fingers extended, traces fairly ample concentric circle in front of him; interpreter $M$ also uses both hands in a bunch and index fingers extended but her concen-

80 They are cohesive insofar as the interpreters produce the same gesture when uttering the same lexical units or different lexical units used to refer to the same semantic content.

81 The other two interpreters omitted the idea of 'recursive quality' from both verbal and gestural modalities. 
tric circles are much smaller in diameter; interpreter I uses both hands slightly cupped in a vertical position with palms facing her breast; her fingers are extended and the circles traced in the air are inwards and not outwards (as in the other 2 cases). All the gestures, however, share an essential trait: 'circularity', associating the quality of 'being recursive' to a circle moving on itself. Moreover, while the speaker expresses this meaning in both speech and gesture, interpreter $M$ produces a gesture for 'recursive quality' but only verbalizes the general concept of 'quality' by saying esta realmente função. Interpreter I does not verbalize the concept of 'recursive quality' at all but enacts it while saying contempla-se a si próprio a contemplar.

\subsection{Example 3: Cutting}

In this example (Table 3), the speaker uses the verbal and gestural modalities to express the meaning of cutting. Note how the short, quick and snappy up-and-down movement of the speaker's left forearm and hand on top of his right hand enhances the meaning expressed in speech (the general verb 'cut') by adding precision to it and showing that the cut was a sudden, single event that affected a specific point in the wire going from the amygdala to the limbic system. All four interpreters translate the semantic unit 'is cut' not only in their speech but also in their forelimb movements in four different ways: a fairly conventionalized scissors movement (M), a biphasic horizontal movement of the right hand (palm down, fingers closed) from left to right (A), a biphasic vertical movement of the right hand (palm vertical, fingers closed) ending on the desk in front of the interpreter (I); a biphasic vertical movement of the right hand (palm vertical, fingers closed) in the air with the left hand mirroring the position of the right hand $(\mathrm{J})$. Note that the interpreters verbalize the meaning 'is cut' by using four different verbs in a construction with passive meaning: tem sido cortado, está destruida, é partido, é quebrado, pode ser interrompida. Their multimodal expression of meaning is as rich and multifaceted as the speaker's expression. 


\section{Preliminary results and their theoretical implications}

The multimodal analysis of simultaneous interpreting data carried out so far (of which we have presented a necessarily limited sample) allows us to give preliminary answers to the questions formulated at the beginning: Do simultaneous interpreters gesture when working in their booths? Are there similarities between the interpreters' speech and accompanying gestures and speakers' speech and accompanying gestures? The results obtained in this and other experiments within this research project as well as in other studies (Adam, 2011) seem to indicate that Portuguese simultaneous interpreters use gestures to a greater or lesser extent while producing discourse. Although we can only speculate as to the reasons why certain simultaneous interpreters seem to rely more on the gestural medium than others, it is fairly safe to assume that personal and cultural factors play an important role 82 . The other factor that seems worth exploring is interpreters' education and acculturation as members of a profession. In this experiment, as well as in another one with the same professional interpreters, the interpreter who produced fewer gestures and movements with a lesser degree of amplitude was the only one who had received formal interpreter education. This may be an indication of the fact that students of interpreting are expected and told to behave in a certain way in the booth (for instance, to limit their gestures). Indeed, an in-depth study of these aspects of interpreting education and of their implications for trainees would be extremely useful.

As regards a possible imitation of the speaker by the interpreters, the results obtained seem to suggest that some of the descriptive gestures produced by the interpreters may be partially similar in form and function to those of the speaker. However, especially when considered together with pragmatic and pointing gestures, the interpreter's gestures

82 It is to be noted that our study focuses exclusively on simultaneous interpreting between English and Continental Portuguese, and does not concentrate on the cultural dimension of spontaneous gestures. 
are autonomous creations and may add other meanings to the verbal component. The accompanying speech is also an autonomous creation of each interpreter since it does not necessarily verbalize the same meaning as expressed in gestures and makes use of different lexical, structural and prosodic resources.

Needless to say, the analysis presented can only afford a brief insight into the multi-layered complexity of meaning construction in SI. We are aware of the many limitations of an experimental approach to the study of SI, which clearly tends to disregard part of the larger picture of the Interpreted Communicative Event (ICE) (Angelelli, 2004: 7) by seeking to simulate an interpreting assignment in a 'test-tube' situation. We are also aware that this approach, by concentrating on the multimodal communication of speaker and interpreter, can create the false impression that these are the only (or the only relevant) participants in an ICE. Notwithstanding all this, we hope that our multimodal descriptive analysis can help shed light on a very simple but nonetheless neglected fact: simultaneous interpreters use their body to produce meaning and they are not just disembodied, neutral filters of an independent meaning produced by a speaker. Besides reinforcing the propositional content of the utterances, simultaneous interpreters' forelimb actions and facial expressions while at work in the booth also reveal their attitudes and emotions, thus having a pragmatic, modal function. ${ }^{83}$

This finding clearly contradicts the idea conveyed by much of the educational and professional discourse on interpreting, which describes interpreters as 'conduits', 'ghosts', 'invisible participants', or 'channels' (Angelelli, 2004: 20). Our view of SI as embodied communication and its focus on the different types of interrelated meanings produced thus adds yet another dimension to the recent view of interpreting as a socially situated practice (Angelelli, 2004).

83 The limited scope of this paper did not allow for an exploration of another interesting pragmatic function of gestures in SI, i.e., gestures used for organizing discourse. 


\section{Bibliographical references}

Adam, Carolin (2011): Gestures in Simultaneous Interpreting. A Descriptive Study. Paper presented at the International Federation of Translators XIX World Congress, San Francisco, USA, August 1-4, 2011.

Angelelli, Claudia V. (2004): Revisiting the Interpreter's Role. Amsterdam: John Benjamins Publishing Company.

Bavelas, J. B. et al. (1995): Gestures specialized for dialogue. In: Personality and Social Psychology Bulletin, 21, 394-405.

de Ruiter, Jan Peter (2000): The production of gesture and speech. In: McNeill, David (ed.): Language and Gesture. Cambridge: Cambridge University Press, 284-311.

Ekman, P. / Friesen, W.V. (1969): The Repertoire of Non-Verbal Behavior: Categories, Origins, Usage and Coding. In: Semiotica, I, I, 49-98.

Kendon, Adam (2004). Gesture. Visible Action as Utterance. Cambridge: Cambridge University Press.

Galhano-Rodrigues, Isabel (2007): Body in interpretation. Nonverbal communication of speaker and interpreter and its relation to words and prosody. In: Schmitt, Peter/ Jüngst, Heike (edd.): Translationsqualität. Leipziger Studien zur angewandten Linguistik und Translaktologie. Frankfurt: Peter Lang Verlag, 739-753.

Goldin-Meadow, Susan (2003): Hearing Gesture: How Our Hands Help Us Think. Cambridge: The Belknap Press of Harvard University Press.

Krauss, Robert M. et al. (2000): Lexical Gestures and lexical access: a process model. In: McNeill, David (ed.): Language and Gesture. Cambridge: Cambridge University Press, 261-283.

McNeill, David (1992): Hand and Mind. What Gestures Reveal About Thought. Chicago: University of Chicago Press.

Pöchhacker, Franz (2004): Introducing Interpreting Studies. London: Routledge.

Selting, Margret et al. (1998): Gesprächsanalytisches Transkriptionssystem (GAT). In: Linguistische Berichte, 173, 91-122.

Zagar Galvão, Elena (2009): Speech and Gesture in the Booth - A Descriptive Approach to Multimodality in Simultaneous Interpreting. In: De Crom, Dries (ed): Selected Papers of the CETRA Research Seminar in Translation Studies 2008. [On-line]. Available at: <http://www.kuleuven.be/cetra/papers/papers.html>

Zagar Galvão, Elena / Galhano-Rodrigues, Isabel (2010): The Importance of Listening with One's Eyes: a Case Study of Multimodality in Simultaneous Interpreting. In: Díaz Cintas, Jorge et al. (edd.): New Insights into Audiovisual Translation and Media Accessibility. Amsterdam: Rodopi. 


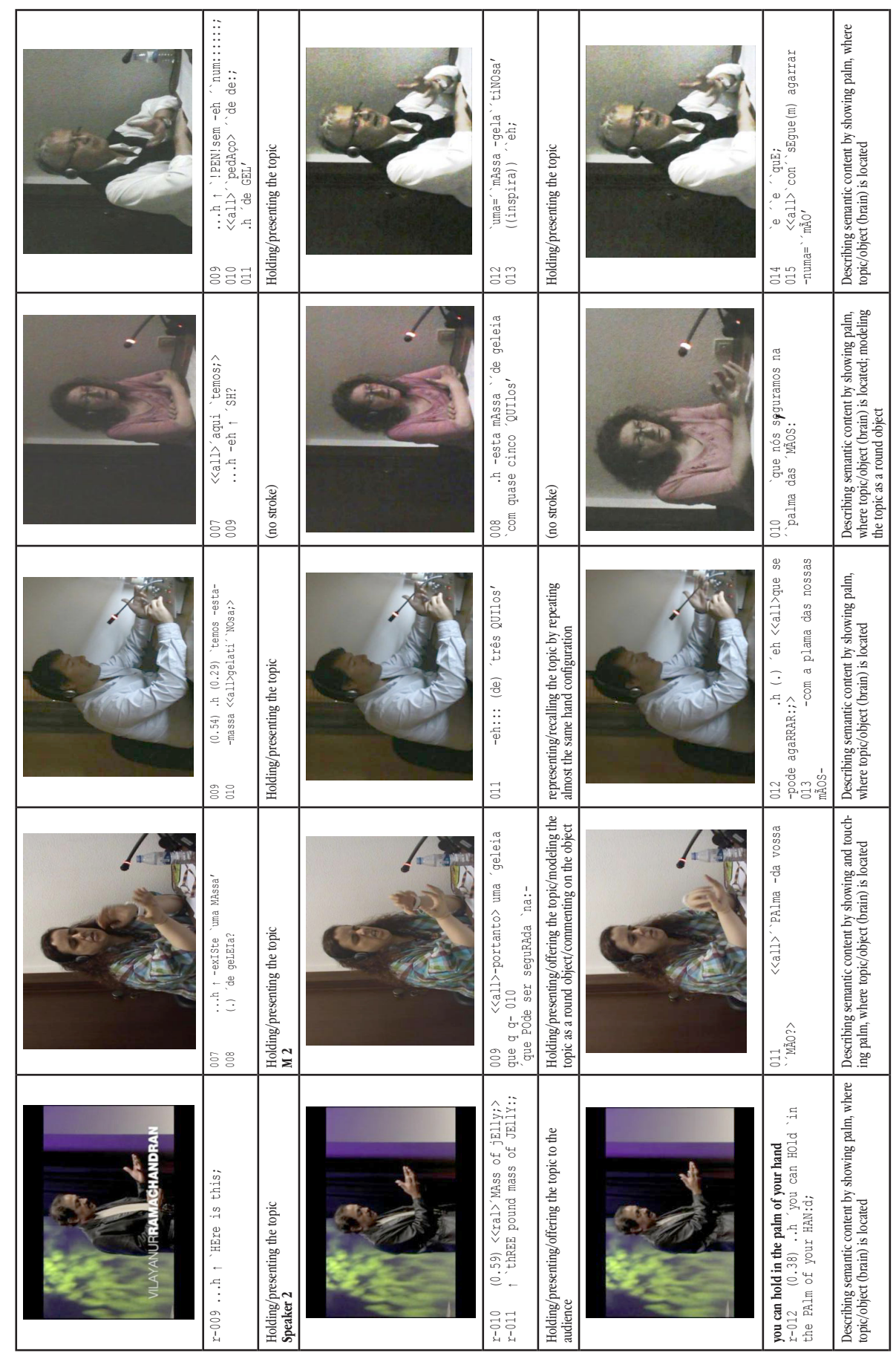

Table 1 


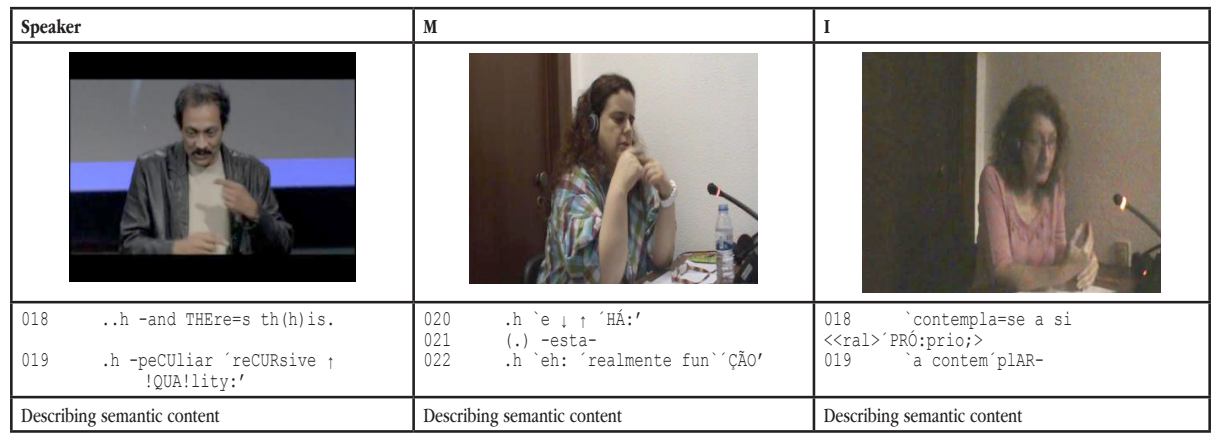

Table 2 - Recursive quality

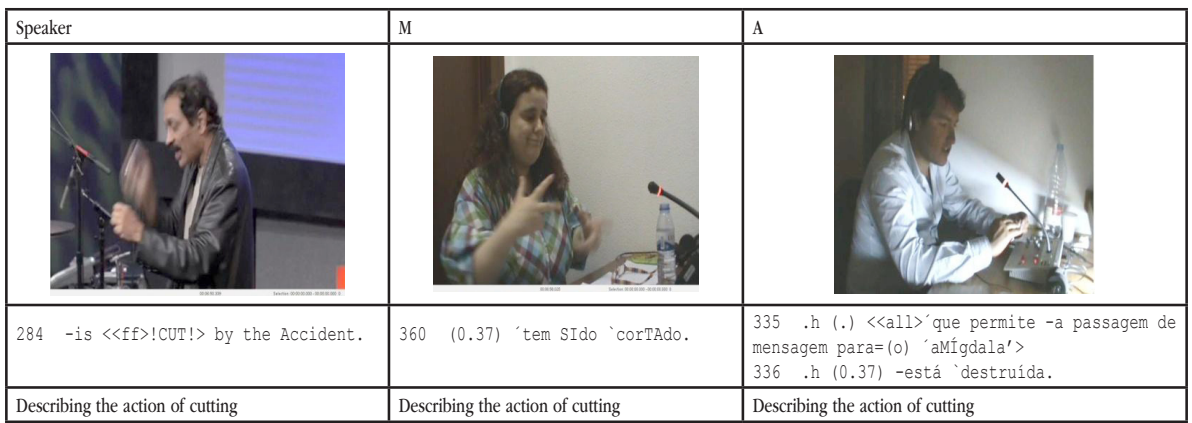

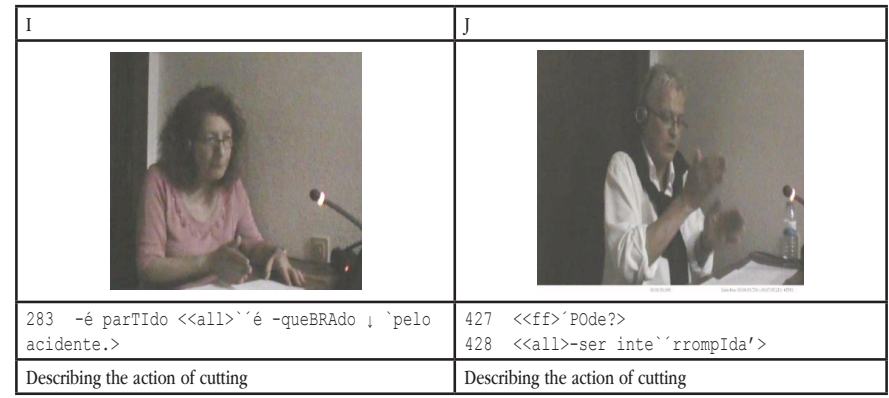

Table 3 - 'Cutting'

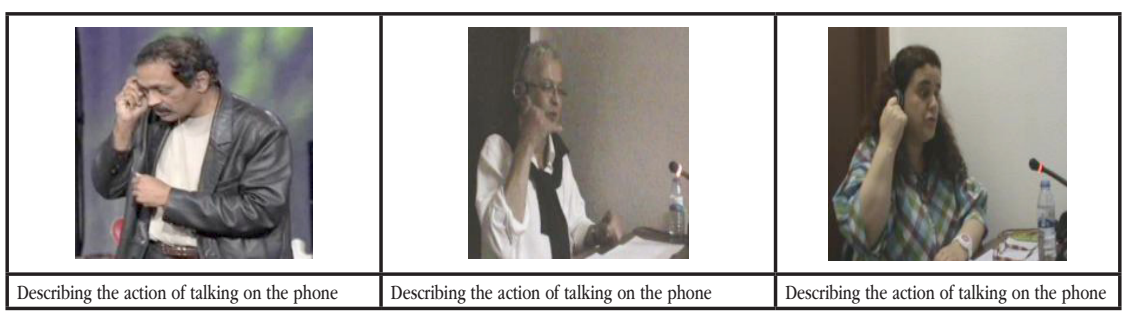

Table 4 - Talking on the phone 